JPE (Jurnal Pendidikan Edutama) Vol. 5 No. 2 Juli 2018

P-ISSN : 2339-2258 (Print) E-ISSN: 2548-821X (Online)

http://ejurnal.ikippgribojonegoro.ac.id/index.php/JPE

\title{
REPRESENTASI SEMBOYAN EDUKASI KI HAJAR DEWANTORO DALAM KAJIAN SEMANTIK (PENDEKATAN BEHAVIORAL)
}

\author{
Agus Hermawan \\ Progam Studi Bahasa Indonesia, Universitas Nahdlatul Ulama Blitar \\ Email:agushermawan8992@gmail.com
}

\begin{abstract}
As a verbal communication instrument, language is a system with arbitrer. People realize that language activity actually is an activity to exspress language symbols to inform the meaning of the symbols to another people (in oral communication) or to the reader (in a letter communication). This thing can be seen from some of these proof, teacher in educational world already forgot about what was Ki Hajar Dewantara said, in that motto, teacher not only have to teach about educational in the class, but also to build the characteristic of their students. This observation use documentation methods in written text or language in the motto of Ki Hajar Dewantara, because Ki Hajar Dewantara wrote a message in that motto about education in the world, including in our environment to send a message about what was he did. The motto that written by Ki Hajar Dewantara use many interesting words. This thing make the writer use behavioral approachment to be a reference to make a meaning of the educational motto from Ki Hajar Dewantara.
\end{abstract}

Keywords: representation, motto, education, meaning.

\begin{abstract}
Abstrak: Sebagai alat komunikasi verbal bahasa merupakan suatu sistem lambang bunyi yang bersifat arbitrer. Orang menyadari bahwa kegiatan berbahasa sesungguhnya adalah kegiatan mengekspresikan lambang - lambang bahasa untuk menyampaikan makna- makna yang ada pada lambang tersebut,kepada lawan bicaranya (dalam komunikasi lisan) atau pembaca ( dalam komunikasi tulis). Hal ini dapat dilihat dari bukti berikut, pendidik dalam dunia pendidikan suda mulai lupa dengan semboyan Ki Hajar Dewantara, dalam semboyan tersebut pendidik tugas dan tanggungjawabnya selain mengajar juga harus membentuk karakteristik peserta didiknya,memberikan contoh dalam bersikap.Penelitian ini menggunakan metode dokumentasi dalam penggunaan bahasa tulis yang dituangkan di semboyan Ki Hajar Dewantara sangatlah menarik, karena Ki Hajar Dewantara menuliskan pesan terhadap dunia pendidikan, baik dilingkungan sekitar maupun dilingkungan luar untuk menyampaikan pesan terhadap apa yang dialaminya. Tulisan Ki Hajar Dewantara tersebut mengandung makna atau arti, apa yang dituliskan Ki Hajar Dewantara banyak menggunakan istilah-istilah yang unik, yang sulit dinalar oleh manusia lainnya. Hal ini menyebabkan penulis menggunakan pendekatan behavioral manjadi acuan untuk memaknai istilah yang ada di semboyan pendidikan Ki Hajar Dewantara.
\end{abstract}

Kata kunci: representasi, semboyan, edukasi, makna.

\section{PENDAHULUAN}

Bahasa dan masyarakat merupakan dua hal yang tidak dapat dipisahkan, sebab keduanya berhubungan erat. Manusia selalu menggunakan bahasa dalam berbagai 
kesempatan dan kepentingan. Bahasa sangat berperan untuk mengungkapkan kemauan atau perasaan dan mengekspresikan apa yang ada di dalam pikirannya kepada orang lain dalam usahanya berinteraksi dengan lingkungan sosialnya Chaer (2007: 2). Eksistensi bahasa dalam konteks sosial tidak dapat diabaikan, karena bahasa manusia dapat mengungkapkan aspek-aspek sosial yang dijumpai ketika berinteraksi dengan lingkungan sosial. Dalam kehidupan seharihari bahasa dibedakan manjadi dua yaitu bahasa tulis dan lisan, bahasa lisan erat kaitannya dengan aktivitas berbicara manusia untuk mangungkapkan pikiran terhadap lawan bicara. Sedangkan, bahasa tulis mengungkapkan segala ide, gagasan dan pikiran melalui tulisan yang mengandung makna dan arti.

Kridalaksana (2004:78) Bahasa juga terdiri dari dua aspek,yaitu aspek lingustik dan aspek nonlinguistik. Aspek lingustik mencakup tataran fonologis,morfologis dan sintaksis. Ketiga tataran ini mendukung terbentuknya yang akan disampaikan, yaitu semantik (yang didalamnya terdapat makna, gagasan, ide, atau konsep). Kajian semantik yang dimanfaatkan untuk menafsirkan makna maupun analisis makna dalam ragam bahasa tertentu. Makna di dalam pemakaian sehari - hari mencakup berbagai bidang dan konteks pemakaian. Kata makna didalam pemakaiannya sering disejajarkan pengertiannya dengan arti, gagasan,pikiran, konsep, pesan,dan informasi Kridalaksana(2004:17) makna adalah pengertian atau konsep yang dimiliki atau terdapat pada sebuah tanda linguistik. Jika tanda linguistik tersebut disamakan identitasnya dengan kata atau leksem, berarti makna adalah pengertian atau konsep yang dimiliki oleh setiap kata atau leksem. Banyak pakar menyatakan bahwa dapat menentukan makna sebuah kata apabila kata itu sudah berada dalam konteks kalimatnya. Pakar itu juga mengatakan bahwa makna kalimat baru dapat ditentukan apabila kalimat itu berada di dalam konteks wacananya atau konteks situasinya.

Bahasa bersifat arbiter, sehingga hubungan antara kata dan maknanya juga bersifat arbiter. Makna juga disejajarkan pengertiannya dengan arti, gagasan, konsep, pernyataan, pesan, informasi, maksud, firasat, dan pikiran. Pengertian makna cenderung lebih dekat dengan pengertian arti, namun bukan berarti keduanya sinonim mutlak. Disebut demikian karena arti adalah kata yang telah mencakup makna dan pengertian, Sehingga pengertian makna terdapat teori pendekatan dan pengembangannya.

Metode dalam pendekatan makna, terdapat tiga pendekatan yang menjadi pijakan dalam pembicaraan masalah makna. Pendekatan referensial yang mengaitkan makna dengan masalah nilai serta proses berpikir manusia dalam memahami realitas lewat bahasa secara benar, pendekatan ideasional mengaitkan makna dengan kegiatan menyusun dan menyampaikan gagasan lewat bahasa, dan pendekatan behavioral mengaitkan makna dengan fakta pemakaian bahasa dalam konteks sosial situasional.

Hasil Kajian Penggunaan bahasa tulis yang dituangkan di semboyan Ki Hajar Dewantara sangatlah menarik, karena $\mathrm{Ki}$ Hajar Dewantara menuliskan pesan terhadap dunia pendidikan, baik dilingkungan sekitar maupun dilingkungan luar untuk menyampaikan pesan terhadap apa yang dialaminya. Tulisan Ki Hajar Dewantara tersebut mengandung makna atau arti, apa yang dituliskan Ki Hajar Dewantara banyak menggunakan istilahistilah yang unik, yang sulit dinalar oleh manusia lainnya. Hal ini menyebabkan 
penulis menggunakan pendekatan behavioral manjadi acuan untuk memaknai istilah yang ada di semboyan pendidikan $\mathrm{Ki}$ Hajar Dewantara.

\section{METODE PENELITIAN}

Penelitian yang berjudul "Representasi Semboyan Edukasi KI Hajar Dewantara dalam kajian semantik (Pendekatan Behavioral), objek penelitiannya adalah isi catatan atau tulisan yang terdapat di semboyan tersebut. Sedangkan yang dikaji dalam penelitian ini adalah makna serta dekripsi makna dalam pendekatan behavioral.

Koenjaraningrat (2014: 109) Penelitian ini memfokuskan pada data tentang bahasa tulis yang terdapat dalam semboyan Ki Hajar Dewantara, dan data tentang makna yang terdapat dalam bahasa tulis di semboyan Ki Hajar Dewantara tersebut. Ini sesuai dengan landasan teori yang dikemukan oleh Chaer (2007: 2) yaitu bahasa bersifat unik,dalam setiap kata atau bahasa mengandung makna atau arti.

Peneliti menggunakan dua pendekatan dalam penelitian ini yaitu secera teoretis dan metodologis. Pendekatan penelitian secara teoritis menggunakan pendekatan semantik, yaitu pendekatan yang mengkaji tentang makna bahasa. Djajasudarma (2006: 4) Makna bahasa merupakan objek studi semantik, dalam makna tersebut terdiri dari satuan -satuan bahasa seperti kata, frase, klausa, kalimat, dan wacana.Berdasarkan penjelasan ini dapat disimpulkan bahwa semantik adalah subdisiplin linguistik yang membicarakan makna. Dengan kata lain semantik berobjekkan makna. Hal ini sesuai dengan penelitian yang dikaji tentang ragam bahasa tulis semboyan Ki Hajar Dewantara.

Pendekatan metodologis yang digunakan peneliti adalah pendekatan kualitatif. peneliti menggunakan pendekatan kualitatif adalah adanya kesesuaian dengan data penelitian. Mahsun (2007: 4), “...metodologi kualitatif sebagai prosedur penelitian yang menghasilkan data deskriptif berupa kata-kata tertulis atau lisan dari orang-orang dan perilaku yang dapat diamati”.

Peneliti juga menggunakan pendekatan behavioral dalam mendeskripsikan makna pada tulisan yang terdapat di semboyan. Pendekatan behavioral menekankan konteks sosial dan situasional untuk menentukan makna. Pada konteks sosial dan konteks situasional tersebut dimana seorang awak truk yang menuliskan ujaran melalui bahasa tulis terhadap lingkungan sekitar tidak lepas dari pengaruh kehidupan sosialnya. Pendekatan behavioral mengaitkan makna dengan fakta pemakaian bahasa dalam konteks sosial situasional.

Metode pengumpulan data berupa metode dokumentasi. Metode dokumentasi yang artinya barang- barang tertulis (Mahsun, 2007: 201). Di dalam melaksanakan metode dokumentasi, peneliti menyelidiki benda- benda tertulis, hal ini menjadi dasar sebagai metode dalam menganalisis bahasa tulis di semboyan $\mathrm{Ki}$ Hajar Dewantara.

Metode dokumentasi ini merupakan metode utama apabila peneliti melakukan pendekatan analasis isi( content analysis).

Selanjutnya,selain menggunakan metode dokumentasi pada penelitian ini menggunakan metode simak, yaitu peneliti menyimak tulisan yang ada pada semboyan Ki Hajar Dewantara. Metode ini memiliki teknik dasar sadap selanjutnya akan diikuti teknik catat.

\section{HASIL DAN PEMBAHASAN}

Hasil Penelitian yang berjudul "Representasi Semboyan Edukasi Ki Hajar Dewantara Kajian Semantik (Pendekatan 
behavioral), pembatasan makna tepacu dalam dua makna yaitu makna kontekstual dan makna konseptual.

\section{a. Makna kontekstual}

Bahasa tulis yang memiliki makna kontekstual semboyan ki hajar Dewantara. Berikut contoh bahasa tulis yang memiliki makna kontekstual.

1. Ing ngarsa sung tuladha ( MKt/B.a/1) Ing Ngarsa Sung Tuladha, artinya seorang guru adalah pendidik yang harus memberi teladan. Ia pantas digugu dan ditiru dalam perkataan dan perbuatannya.

2. Ing madya mangun karsa ( MKt/B.a/2)

Ing Madya Mangun Karsa, artinya seorang guru adalah pendidik yang selalu berada di tengah-tengah para muridnya dan terus-menerus membangun semangat dan ide-ide mereka untuk berkarya.

3. Tut wuri Handayani ( MKt/B.a/3)

Tut Wuri Handayani, artinya seorang guru adalah pendidik yang terusmenerus menuntun, menopang dan menunjuk arah yang benar bagi hidup dan karya anak-anak didiknya.

Dari ketiga semboyan diatas mengandung kontesks maksud yang jelas pendidikan merupakan bagian dari perkembangan budi pekerti anak-anak sebab pendidikan demikian membangun budi karakter pekerti anak-anak. Paksaan dan hukuman dalam proses pendidikan yang kadangkala tidak setimpal dengan kesalahan anak didik bukannya memperkuat mentalitas anak-anak, melainkan memperlemahnya di kemudian hari. Anak tidak menjadi pribadi yang mandiri, tidak memiliki inisiatif, tidak kreatif. Dalam kehidupan nyata ia tidak dapat bekerja kalau tidak dipaksa dan diperintah. Jadi, produk pendidikan barat, di hadapan Ki Hadjar, adalah manusiamanusia pasif yang dangkal kesadarannya untuk berkreasi secara mandiri.

\section{b. Makna konseptual}

Bahasa tulis yang memiliki makna konseptual semboyan ki hajar Dewantara. Berikut contoh bahasa tulis yang memiliki makna kontekstual.

1. Ing ngarsa sung tuladha ( MKs/B.a/1)

Ing Ngarsa Sung Tuladha, artinya seorang guru adalah pendidik yang harus memberi teladan. Ia pantas digugu dan ditiru dalam perkataan dan perbuatannya. 2. Ing madya mangun karsa ( MKs/B.a/2)

Ing Madya Mangun Karsa, artinya seorang guru adalah pendidik yang selalu berada di tengah-tengah para muridnya dan terus-menerus membangun semangat dan ide-ide mereka untuk berkarya.

\section{Tut wuri Handayani ( MKs/B.a/3 )}

Tut Wuri Handayani, artinya seorang guru adalah pendidik yang terusmenerus menuntun, menopang dan menunjuk arah yang benar bagi hidup dan karya anak-anak didiknya.

Dari ketiga semboyan diatas terdapat makna konseptual yang terbentuk oleh kemauan tekad dan ide ki Hajar Dewantara tentang dunia pendidikan adalah Metode Ngemong, Momong, Among dan semboyan Ing ngarso sung tulodho, Ing Madya mangun karsa, dan Tut wuri handayani bukan berasal dari sebuah pemikiran Ki Hadjar Dewantara yang terpisah. Pendidikan bukan hanya masalahbagaimana membangun isi (kognisi) namun juga pekerti (afeksi) anakanak Indonesia, yang tentunnya diharapkan "meng-Indonesia" agar mereka kelak mampu menjadi pemimpin-pemimpin bangsa yang "meng-Indonesia" (memiliki kekhasan Indonesia).

\section{c. Pendekatan behavioral}

Berikut merupakan data deskripsi tenatng kajian makna dalam pendekatan behavioral.

1. Ing ngarsa sung tuladha 
Data (1) memiliki pendekatan behavioral, sesuai dengan konteks dan tidak dipengaruhi oleh situasi. Makna "ing ngarsa sung tuladha", dalam pendekatan behavioral yaitu bagaimana harapan dari ki hajar dewantara dalam dunia pendidikan seorang guru bisa memberikan contoh.

2. Ing madya mangun karsa

Data (2) memiliki makna pendekatan behavioral,sesuai dengan konteks dan tidak dipengaruhi oleh situasi. Makna "ing madya mangun karsa", dalam pendekatan behavioral yaitu bagaimana harapan dari ki hajar dewantara dalam dunia pendidikan seorang guru bisa memberikan contoh.

\section{Tut wuri handayani}

Data (3) memiliki makna pendekatan behavioral,sesuai dengan konteks dan tidak dipengaruhi oleh situasi. Makna "tut wuri handayani", dalam pendekatan behavioral yaitu bagaimana harapan dari ki hajar dewantara dalam dunia pendidikan seorang guru bisa memberikan contoh,

Berdasarkan data di atas dapat disimpulkan Menurut Ki Hadjar Dewantara, metode pendidikan yang cocok dengan karakter dan budaya orang Indonesia tidak memakai syarat paksaan. Orang Indonesia adalah termasuk ke dalam bangsa timur.

Berdasarkan data di atas dapat disimpulkan Menurut Ki Hadjar Dewantara, metode pendidikan yang cocok dengan karakter dan budaya orang Indonesia tidak memakai syarat paksaan. Orang Indonesia adalah termasuk ke dalam bangsa timur. Bangsa yang hidup dalam khasanah nilainilai tradisional berupa kehalusan rasa, hidup dalam kasih saying, cinta akan kedamaian, ketertiban, kejujuran dan sopan dalam tutur kata dan tindakan. Nilai-nilai itu disemai dalam dan melalui pendidikan sejak usia dini anak. Dalam praksis penyemaian nilai-nilai itu, pendidik menempatkan peserta didik sebagai subyek, bukan obyek pendidikan. Artinya, peserta didik diberi ruang yang seluasnya untuk melakukan eksplorasi potensipotensi dirinya dan kemudian berekspresi secara kreatif, mandiri dan bertanggungjawab.

Senada dengan semboyan pendidikan di atas adalah metode pendidikan yang dikembangkan, yang sepadan dengan makna "paedagogik", yakni Momong, Among dan Ngemong, yang berarti bahwa pendidikan itu bersifat mengasuh. Mendidik adalah mengasuh anak dalam dunia nilai-nilai. Praksis pendidikan dalam perspektif ini memang mementingkan ketertiban, tapi pelaksanaannya bertolak dari upaya membangun kesadaran, bukan berdasarkan paksaan yang bersifat "hukuman". Maka, pembagian usia 0-7, 7-14, dan 14-21 dalam proses pendidikan yang digagas Ki Hadjar Dewantara bukan tanpa landasan pedagogik. Pembagian demikian berdasarkan fase-fase di mana masingmasing menuntut peran pendidik dengan isi dan nilai yang berbeda-beda.

Praktis pendidikan berdasarkan metode Ki Hadjar Dewantara menempatkan guru sebagai pengasuh yang matang dalam penghayatan dan pelaksanaan nilai-nilai kultural yang khas Indonesia. Maka pendidikan pada dasarnya adalah proses mengasuh anak-anak untuk bertumbuh dan berkembang dalam potensi-potensi diri (kognisi, afeksi, psikomotorik, konatif, kehidupan sosial dan spiritual). Dalam rangka itu, guru tidak menggunakan metode paksaan, tapi memberi pemahaman sehingga anak mengerti dan memahami yang terbaik bagi dirinya dan lingkungan sosialnya. Guru boleh terlibat langsung dalam kehidupan anak tatkala anak itu dipandang berada pada jalan yang salah. Tapi pada prinsipnya tidak bersifat paksaan. 


\section{SIMPULAN}

Bahasa merupakan media komunikasi utama manusia dalam menyampaikan gagasan. Sebagai alat komunikasi verbal bahasa merupakan suatu sistem lambang bunyi yang bersifat arbitrer. Orang menyadari bahwa kegiatan berbahasa sesungguhnya adalah kegiatan mengekspresikan lambang-lambang bahasa untuk menyampaikan makna- makna yang ada pada lambang tersebut,kepada lawan bicaranya (dalam komunikasi lisan) atau pembaca (dalam komunikasi tulis).

Bahasa tulis yang terdapat "Representasi Semboyan Edukasi Ki Hajar Dewantara Kajian Semantik (Pendekatan behavioral) tersebut mengandung makna atau arti, apa yang dituliskan ki Hajar Dewantara banyak menggunakan istilahistilah yang unik, yang sulit dinalar oleh manusia lainnya. Hal ini menyebabkan penulis menggunakan pendekatan behavioral manjadi acuan untuk memaknai istilah yang ada di semboyan tersebut.

Pendekatan behavioral menekankan konteks sosial dan situasional untuk menentukan makna. Pada konteks sosial dan konteks situasional tersebut dimana seorang Ki Hajar Dewantara yang menuliskan ujaran melalui bahasa tulis terhadap dunia pendidikan dimasa itu, tidak lepas dari pengaruh kehidupan sosialnya.

\section{DAFTAR RUJUKAN}

Chaer, A. (2007). LinguistikUmum. Jakarta: PT RinekaCipta.

Djajasudarma, F. (2006). Metode Linguistik. Jakarta: Refika Aditama.

Dewantara, K. H. (1954). Masalah Kebudayaan. Pertjetakan Taman Siswa, Jogjakarta.

1962. Karja I (Pendidikan). Pertjetakan Taman Siswa, Jogjakarta.

Kridalaksana. (2004). Leksikon komunikasi. Jakarta: Gramedia.

Koentjaraningrat. (2014). Kebudayaan Mentalitas dan Pembangunan. Jakarta : Gramedia.

Mahsun, M. S. (2007). Metode Penelitian Bahasa: Tahapan Strategi, Metode, dan Tekniknya. Jakarta: PT. Raja Grafindo Persada.

Soeratman, D. (1995). Ki Hadjar Dewantara, Departemen Pendidikan dan Kebudayaan, Jakarta. 